\title{
Impact of organic fertilizers on yield and nutrient uptake of cabbage (Brassica oleracea var. capitata)
}

\section{Md. Selim Reza1, A. K. M. Sajjadul Islam², Md. Asif Rahman³, Md. Yunus Miah¹, Sohela Akhter $^{4}$ and Md. Mosheur Rahman ${ }^{5}$}

${ }^{1}$ Dept. of Soil Science, Bangabandhu Sheikh Mujibur Rahman Agricultural University, Gazipur-1706, Bangladesh

${ }^{2}$ Hybrid Rice Division, BRAC Agricultural Research and Development Centre, Gazipur-1701, Bangladesh 3Dept. of Genetics and Plant Breeding, Bangabandhu Sheikh Mujibur Rahman Agricultural University,

Gazipur-1706, Bangladesh

${ }^{4}$ Soil Science Division, Bangladesh Agricultural Research Institute, Gazipur-1701, Bangladesh 5Dept. of Environmental Science, Bangabandhu Sheikh Mujibur Rahman Agricultural University, Gazipur-1706, Bangladesh

Article info.

Key Words:

Vermicompost, Treatments, Cabbage, Growth, Soil

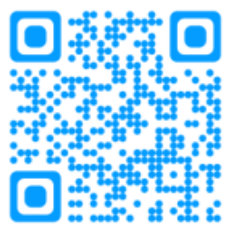

Received: 16.07.2016 Published: 14.08.2016

For Any Information:

ask.author@journalbinet.com
ABSTRACT

Goal of the study was to investigate nutrient uptake, growth and yield of the cabbage (Brassica oleracea var. capitata) variety'Atlas-70'as influenced by the application of different organic fertilizers. Randomized complete block design (RCBD) comprising five treatments with three replications were executed to conduct the study. Treatments were $T_{1}=$ Soil Test Based 100\% Recommended Dose of Chemical Fertilizer (RDCF), $T_{2}=5 \mathrm{t} / \mathrm{ha}$ Cow dung (CD) + integrated plant nutrient system (IPNS) based Chemical fertilizers (CF), $T_{3}=5$ t/ha Poultry Manure (PM) + integrated plant nutrient system (IPNS) based Chemical fertilizers (CF), $T_{4}=5 \mathrm{t} / \mathrm{ha}$ vermicompost $(\mathrm{VC})+$ integrated plant nutrient system (IPNS) based Chemical fertilizers (CF), $T_{5}=$ Absolute control. Results of the experiment showed that the same amount of $N, P$, $K$ and $S$ from cow dung, poultry manure and vermicompost showed significant differences $(P \leq 0.05)$ on plant height, unfolded leaves, head circumference, marketable yield, total yield and nutrient content in cabbage. Organic fertilizers (cow dung, poultry manure and vermicompost) resulted better nutrient uptake as compared to the chemical fertilizers. However, vermicompost tended to be the potential organic source for higher yield and nutrient uptake of cabbage and thus is suitable substitute of the most commonly used nitrogen (urea) sources for the production of cabbage. 
Citation (APA): Reza, M. S., Islam, A. K. M. S., Rahman, M. A., Miah, M. Y., Akhter, S. \& Rahman, M. M. (2016). Impact of organic fertilizers on yield and nutrient uptake of cabbage (Brassica Oleracea var. capitata). Journal of Science, Technology and Environment Informatics, 03(02), 231-244.

(C) 2016, Reza et al. This is an open access article distributed under terms of the Creative Common Attribution 4.0 International License.

\section{Introduction}

Cabbage (Brassica oleracea L.) is a member of cole crops under the family Brassiceae. It is one of the popular vegetable grown in winter season of Bangladesh. It is low in fat, high in dietary fibre, foliate, water and vitamin $\mathrm{C}$, processing a very high nutritional density which can help to protect a range of diseases from cancer to cataract (Krish et al., 2007). In addition to containing B vitamins, cabbage supplies potassium and calcium to the diet.

Imbalance use of chemical fertilizer in vegetable and other crop production is a common practice in Bangladesh. The yield of vegetable crops declined due to depleted soil fertility. Organic manuring can play a vital role in sustaining soil fertility and crop production. It is a fact that use of inorganic fertilizers for the crops is not so good for soil health because of residual effect while organic fertilizer does not create such problem. Moreover, it increases the productivity of soil as well as crop quality and yield (Tindall, 2000). The farmers use chemical fertilizers as a readily supplemental source of nutrients but they do not apply in balanced proportion (BARC, 2005). Moreover, organic matter content in Bangladesh soils is very low $(<1.5 \%)$ and is being gradually depleted (Ali et al., 1997). Neither the chemical fertilizer nor organic manure alone can help in achieving sustainable crop production. Even with balanced use of only chemical fertilizer, high yield level could not be maintained over the years because of deterioration in soil physical, chemical and biological properties (Khan et al., 2008). The integrated nutrient management is the best approach to maintain soil fertility and productivity on sustainable basis.

Cowdung is a good source of $\mathrm{N}, \mathrm{P}, \mathrm{K}$ and $\mathrm{S}$ which is responsible for the higher yield of cabbage. Batsai et al. (1997) reported that chemical fertilizers along with the organic fertilizers (cowdung) produced the highest cabbage yields. Poultry manure is especially suitable for acid soils as it has strong liming effect. It reduces the acidity of the soils and thereby protects crops from aluminum toxicity. These organic fertilizers can effectively be utilized for organic farming for high value crops that is the demand of the day in Bangladesh and elsewhere. On the other hand, utilization of earthworms to decompose and stabilize organic wastes has received increasing interest and popularity in recent years (Kale and Bano, 1986). Organic wastes when subject to decompose with the help of earthworms, the resultant product is vermicompost and the process is known as vermicomposting. Vermicomposting has been reported to be viable, cost effective and rapid technique for the efficient management of the solid wastes (Payal et al., 2006). Vermicomposting is a suitable technology for decomposition of different types of organic waste (domestic as well as industrial) into value added material. The earthworm species Eiseniafetida is mainly used for vermicomposting. Vermicomposting is a potential source of readily available nutrients, growth enhancing substances and a number of beneficial microorganisms like $\mathrm{N}$ fixing, $\mathrm{P}$ solubilizing and cellulose decomposing organisms (Suthar, 2012). Vermicompost contains more organic matter, nitrogen, phosphorous, sulphur, calcium and magnesium (Zahid, 2001). It not only helps to improve and protect the soil fertility of top soil but also helps to boost productivity by $40 \%$ with 20 to $60 \%$ lower nutrient inputs (Sunassee, 2001). Keeping these in mind, the preset investigation has been undertaken to evaluate the effect of combined application of inorganic and organic fertilizer on growth and yield of cabbage.

\section{Materials and Methods}

Experiment site and design: The experiment was carried out at the experimental field of Department of Soil Science of Bangabandhu Sheikh Mujibur Rahman Agricultural University (BSMRAU), Gazipur, 
Bangladesh during the period from November 2014 to February 2015. The experiment was laid out in a Randomized Complete Block Design (RCBD) with three replications and five treatments. There were 15 plots; each having the dimension of $3 \mathrm{~m} \times 2 \mathrm{~m}=6 \mathrm{~m}^{2}$. Distance between replication to replication was 1 $\mathrm{m}$ and Line to line $60 \mathrm{~cm}$, plant to plant $40 \mathrm{~cm}$. However, the five treatments of the experiment were as follows, $\mathrm{T}_{1}=$ Soil Test Based 100\% Recommended Dose of Chemicals Fertilizers, $\mathrm{T}_{2}=$ Cow Dung (5 ton/ha) + IPNS based CF, $\mathrm{T}_{3}=$ Poultry Manure ( 5 ton/ha) + IPNS based CF, $\mathrm{T}_{4}=$ Vermicompost ( 5 ton/ha) + IPNS based CF, $\mathrm{T}_{5}=0$ (Absolute control) and RDCF $=\mathrm{N}_{201} \mathrm{P}_{73} \mathrm{~K}_{58} \mathrm{~S}_{20} \mathrm{~kg} \mathrm{ha}^{-1}$

Soil sampling and analysis: Soil samples to a depth of 0-15 $\mathrm{cm}$ were collected before initiation of the experiment and after harvesting of crops. Before initiation and the completion of the experiments, composite soil samples were collected from each plot (three replications) at 0-15 cm depth. Three auger samples were taken from each plot and divided into two sets of sub-samples. The collected samples were then air dried and ground to pass through a $2 \mathrm{~mm}$ (10 meshes) sieve and stored in a clean plastic container for physical and chemical analyses. Then after harvesting of cabbage, soil sample was collected from each plot. After removal of all debris, composite soil sample was made by treatment wise and the soil was labeled as post soil. The soil was air dried in room temperature in the laboratory. Then $\mathrm{pH}$, organic carbon (\%), total $\mathrm{N}(\%)$, available P (ppm), exchangeable K (meq/100g soil), Ca, Mg, S, Zn, B and all other physical and chemical properties were analyzed of initil soil as presented in Table 01 by the standard methods of Jackson (1973); Nelsons and Sommers (1982); Black(1965); Olsen and Sommers (1982); Thomas (1982).

Table 01. Initial physical and chemical soil properties of the experimental site

\begin{tabular}{|c|c|}
\hline Soil characteristics & Analytical value \\
\hline \multicolumn{2}{|c|}{ Physical properties } \\
\hline Sand & $17.2 \%$ \\
\hline Silt & $47.2 \%$ \\
\hline Clay & $35.6 \%$ \\
\hline Textural class & Silt clay loam \\
\hline Bulk density & $1.4 \mathrm{~g} / \mathrm{cm}^{3}$ \\
\hline Particle density & $2.6 \mathrm{~g} / \mathrm{cm} 3$ \\
\hline \multicolumn{2}{|c|}{ Chemical properties } \\
\hline Soil pH & 6.2 \\
\hline Total N (\%) & 0.058 \\
\hline Organic C (\%) & 0.8 \\
\hline $\mathrm{C}: \mathrm{N}$ ratio & 13.79 \\
\hline Available P (ppm) & 10 \\
\hline Exchangeable K (meq/100 g) & 0.13 \\
\hline Exchangeable Ca (meq/100 g) & 8.75 \\
\hline Exchangeable Mg (meq/100g) & 2.46 \\
\hline Available S (ppm) & 15 \\
\hline Available B (ppm) & 0.20 \\
\hline Zinc (ppm) & 1.1 \\
\hline
\end{tabular}

Vermicompost and organic manure analysis: Vermicompost was collected from Bangladesh Agricultural Research Institute (BARI), Joydebpur, Gazipur, Bangladesh.

Organic manures analysis (cowdung, poultry manure and vermicompost) for $P, K, S, Z n$ determination: The sample weighing $1 \mathrm{~g}$ was transferred into a dry clean $100 \mathrm{ml}$ beaker, then $10 \mathrm{ml}$ $\mathrm{HNO}_{3}$ was added, boiled gently till the content became almost dry. After cooling the content, $5 \mathrm{ml} \mathrm{HClO}_{4}$ was added, boiled gently until the solution became colorless or nearly so and dense white fumes fill the beaker. The contents of the flask were boiled until they became sufficiently clean and colorless. The contents were then transferred to a $100 \mathrm{ml}$ volumetric flask by washing with distilled water through a 
Whatman filter paper no. 1. A blank was also digested without chemicals. The P, K, S and Zn contents were determined from this digest by the standard method of Olsen and Sommers (1982); Jackson (1973); Thomas (1982).

\section{Organic manures (cowdung, poultry manure and vermicompost) for nitrogen determination:}

An amount of $1 \mathrm{~g}$ vermicompost sample was taken into a $100 \mathrm{ml}$ Micro-Kjeldahl digestion flask. Into the flask, $10 \mathrm{ml} \mathrm{H}_{2} \mathrm{O}$ and $15 \mathrm{ml}$ conc. $\mathrm{H}_{2} \mathrm{SO}_{4}$ were added and heated for 10 minutes. Then $5 \mathrm{~g}$ digestion mixture $\left(\mathrm{K}_{2} \mathrm{SO}_{4}: \mathrm{CuSO}_{4} \cdot \mathrm{H}_{2} \mathrm{O}\right.$, Se $\left.=100: 10: 5.1\right)$ was added in it after cooling the flask was swirled and allowed to stand for about 10 minutes, followed by continuous heating till the digest was clean and colorless. After cooling, the contents were transferred into a $100 \mathrm{ml}$ volumetric flask and the volume was made with distilled water. A reagent blank was prepared in a similar manner by the standard method of Black (1965).

Table 02. Nutrient status of the organic manure

\begin{tabular}{lllll}
\hline \multirow{2}{*}{ Organic manure } & \multicolumn{4}{c}{ Contents (\%) } \\
\cline { 3 - 5 } & $\mathrm{N}$ & $\mathrm{P}$ & $\mathrm{K}$ & $\mathrm{S}$ \\
\hline Cowdung & 0.57 & 0.21 & 0.56 & 0.20 \\
Poultry manure & 0.80 & 0.28 & 1.36 & 0.23 \\
Vermicompost & 0.90 & 0.66 & 1.80 & 0.60 \\
\hline
\end{tabular}

Variety and application of fertilizers and manures: Atlas-70 Cabbage variety was used in this experiment. Thirty five days old seedlings were transplanted in the experimental field. The doses of $100 \% \mathrm{~N}-\mathrm{P}-\mathrm{K}-\mathrm{S}$ were $201-73-58-20 \mathrm{~kg} \mathrm{ha}^{-1}$, respectively and these were used in the form of Urea, TSP (triple super phosphate), MoP (muriate of potash), Gypsum. The whole amount of $\mathrm{P}, \mathrm{K}, \mathrm{S}$ and $1 / 3 \mathrm{~N}$ were broadcast and thoroughly incorporated into the soil at the time of final land preparation and the remaining $2 / 3 \mathrm{~N}$ was top dressed in two equal installation at 25 and 45 days after transplanting. Cow dung, poultry manure and vermicompost were applied in the field before transplanting.

Requirement of N, P, K and S: For high yield of cabbage, the required amount of urea, triple super phosphate (TSP), muriate of potash (MoP) and gypsum as source of N, P, K and S, respectively were calculated based on the book of Bangladesh Agricultural Research Council (BARC, 2012).

\section{Table 03. Application of inorganic fertilizers based on the treatment $(\mathrm{kg} / \mathrm{ha})$}

\begin{tabular}{c|cccc}
\hline \multirow{2}{*}{ Treatments } & \multicolumn{4}{|c}{ Total nutrient added (kg/ha) } \\
\cline { 2 - 5 } & $\mathrm{N}$ & $\mathrm{P}$ & $\mathrm{K}$ & $\mathrm{S}$ \\
\hline $\mathrm{T}_{1}(100 \%$ RDCF $)$ & 201 & 73 & 58 & 20 \\
$\mathrm{~T}_{2}$ (CD+IPNS based CF) & 187 & 68 & 44 & 15 \\
$\mathrm{~T}_{3}$ (PLM+IPNS based CF) & 182 & 66 & 24 & 14 \\
$\mathrm{~T}_{4}$ (VC+IPNS based CF) & 179 & 57 & 13 & 5 \\
$\mathrm{~T}_{5}$ (Absolute control) & 0 & 0 & 0 & 0
\end{tabular}

Mineralization rate for organic fertilizer is about $40 \%$

IPNS= Integrated Plant Nutrient System, RDCF= Recommended Doses Chemical Fertilizers, CD= Cowdung (5 t/ha), PLM= Poultry manure ( $5 \mathrm{t} / \mathrm{ha}), \mathrm{VC}=$ Vermicompost $(5 \mathrm{t} / \mathrm{ha})$.

Collection of data and analysis: The data pertaining to plant height $(\mathrm{cm})$, number of unfolded leaves per plant, head circumferences $(\mathrm{cm})$, head height $(\mathrm{cm})$, total weight $(\mathrm{kg} / \mathrm{plant})$, marketable weight ( $\mathrm{kg} / \mathrm{plant}$ ), total yield ( $\mathrm{t} / \mathrm{ha}$ ) and marketable yield ( $\mathrm{t} / \mathrm{ha}$ ) characters were recorded from randomly selected 5 cabbage plants. After harvest, plant samples from each plot were collected and divided into stalk and head. The plant samples were analyzed for N, P, K, S, Zn, B, Ca and Mg contents. The samples were cleaned, dried and chemical analysis was performed by the methods of Piper (1966). On the other hand, post harvest chemical analysis of soil were determined on $\mathrm{pH}$, organic carbon, $\mathrm{N}, \mathrm{P}, \mathrm{K}, \mathrm{S}, \mathrm{Zn}, \mathrm{B}, \mathrm{Ca}$ 
and Mg. The standard methods were (Black, 1965) for N estimation, (Olsen and Sommers, 1973) for P and organic cabon estimation, (Jackson, 1973) for $\mathrm{pH}, \mathrm{K}, \mathrm{Ca}, \mathrm{Mg}$ and $\mathrm{Zn}$ estimation, (Thomas, 1982) for S and $\mathrm{B}$ estimation for soil analysis. Analysis of variance was done following the Randomized Complete Block Design (RCBD) with the help of computer package statistical 10. The data were analyzed statistically by F-test. The mean differences of the treatments were observed by least significant difference (LSD) test at 5\% level of probability for the interpretation of results (Gomez and Gomez, 1984).

\section{Results and Discussion}

\section{Effect of organic and inorganic fertilizers on the growth and yield of cabbage}

\section{Plant height}

The effect of cow dung, poultry manure and vermicompost in combination with inorganic fertilizer on the plant height of cabbage have been presented in Table 04. Significant variation $(P \leq 0.05)$ was observed in plant height of cabbage when vermicompost, cowdung and poultry manure were incorporated into the soil. Among the treatments, $\mathrm{T}_{4}$ treatment showed the highest plant height (34.9 $\mathrm{cm}$ ) of cabbage. On the other hand, the lowest plant height $\left(24.2 \mathrm{~cm}\right.$ ) was observed in $\mathrm{T}_{5}$ (control) treatment where no organic or inorganic fertilizer was applied. Vermicompost is a tea like structure organic fertilizer which is more nutrient rich than the other organic fertilizers and might have improved the soil porosity, structure, water holding capacity and supplied other plant growth promoting substances and hence vermicompost significantly increased plant height. Similar result was reported by other researchers (Walker and Bernal, 2004).

\section{Number of unfolded leaves per plant}

Numbers of unfolded leaves of cabbage were decreased in organic fertilizer treated plots under the present study (Table 04). There was significant variation in the number of unfolded leaves plant ${ }^{-1}$ due to application of different organic and inorganic fertilizers. The highest (16) number of unfolded leaves in cabbage was observed in $\mathrm{T}_{5}$ treatment where no fertilizers was used (control) and the lowest was recorded in $\mathrm{T}_{4}(9)$ where $5 \mathrm{t}$ /ha vermicompost was applied along with IPNS based chemical fertilizer. Comparing with $\mathrm{T}_{1}$ treatment, it was observed that more number of unfolded leaves were produced in $\mathrm{T}_{1}$ treatment (16) than $\mathrm{T}_{2}(11), \mathrm{T}_{3}(10)$ and $\mathrm{T}_{4}(9)$ treatments where organic fertilizers were used with IPNS based chemical fertilizers. From Table 4, it was also revealed that vermicompost treated plots with IPNS based chemical fertilizers produced less unfolded leaves compared to the other organic fertilizer treatments. Organic fertilizers should be incorporated with inorganic fertilizer for expected outcome through IPNS. Similar result was reported by Walker and Bernal (2004). Organic fertilizers help in constructing the leaves of cabbage to form the cabbage head. The more the unfolded leaves, the less the head form of cabbage. From this point of view, vermicompost resulted the best performance in constructing cabbage head than the other organic fertilizers with the same amount of application.

\section{Head circumference}

Significant $(\mathrm{P} \leq 0.05)$ variation was observed in head circumference of cabbage as influenced by different types of organic fertilizers with inorganic fertilizers. The highest head circumference $(75.0 \mathrm{~cm})$ was observed in $\mathrm{T}_{4}$ treatment (Table 04). The lowest circumference $(49.2 \mathrm{~cm})$ was obtained from $\mathrm{T}_{5}$ treatment. Among the treatments, $\mathrm{T}_{4}$ showed the highest head circumference which was significantly higher than $\mathrm{T}_{1}, \mathrm{~T}_{2} \mathrm{~T}_{3}$ and $\mathrm{T}_{5}$ treatments. A similar result was found by Blatt (1991). 
J. Sci. Technol. Environ. Inform. 03(02): 231-244 | Reza et al. (2016)

EISSN: 2409-7632, www.journalbinet.com

DOI: $10.18801 /$ jstei.030216.26

Table 04. Effect of organic and inorganic fertilizers on growth and yield of cabbage

\begin{tabular}{ccccccc}
\hline Treatments & $\begin{array}{c}\text { Plant } \\
\text { height (cm) }\end{array}$ & $\begin{array}{c}\text { Number of } \\
\text { unfolded } \\
\text { leaves } \\
\text { plant }-1\end{array}$ & $\begin{array}{c}\text { Head } \\
\text { circumferences } \\
\text { (cm) }\end{array}$ & $\begin{array}{c}\text { Head } \\
\text { height }(\mathrm{cm})\end{array}$ & $\begin{array}{c}\text { Total } \\
\text { weight } \\
\text { (kg/plant) }\end{array}$ & $\begin{array}{c}\text { Marketable } \\
\text { weight } \\
\text { (kg/plant) }\end{array}$ \\
\hline $\mathrm{T}_{1}$ & $30.1 \mathrm{~d}$ & $12 \mathrm{~b}$ & $68.7 \mathrm{~d}$ & $10.6 \mathrm{~d}$ & $2.1 \mathrm{c}$ & $1.9 \mathrm{c}$ \\
$\mathrm{T}_{2}$ & $32.8 \mathrm{c}$ & $11 \mathrm{bc}$ & $71.0 \mathrm{c}$ & $12.4 \mathrm{c}$ & $2.2 \mathrm{~b}$ & $2.1 \mathrm{~b}$ \\
$\mathrm{~T}_{3}$ & $33.8 \mathrm{~b}$ & $10 \mathrm{~cd}$ & $73.6 \mathrm{~b}$ & $13.0 \mathrm{~b}$ & $2.3 \mathrm{ab}$ & $2.2 \mathrm{ab}$ \\
$\mathrm{T}_{4}$ & $34.9 \mathrm{a}$ & $9 \mathrm{~d}$ & $75.0 \mathrm{a}$ & $14.2 \mathrm{a}$ & $2.4 \mathrm{a}$ & $2.3 \mathrm{a}$ \\
$\mathrm{T}_{5}$ & $24.2 \mathrm{e}$ & $16 \mathrm{a}$ & $49.2 \mathrm{e}$ & $8.1 \mathrm{e}$ & $1.1 \mathrm{~d}$ & $1.0 \mathrm{~d}$ \\
$\mathrm{LSD}_{0.05}$ & 0.93 & 1.0472 & 0.65 & 0.29 & 0.1140 & 0.1417 \\
$\mathrm{CV} \%^{1.59}$ & 4.66 & 0.51 & 1.33 & 2.97 & 3.91 \\
\hline
\end{tabular}

In a column figures having similar letter (s) do not differ significantly whereas figures with dissimilar letter (s) differ significantly as per LSD at 5\% level of probability.

\section{Head height of cabbage}

Statistically significant $(\mathrm{P} \leq 0.05)$ variation was observed for head height of cabbage with the application of organic fertilizers (Table 04). Combined application of different organic fertilizers (cowdung, poultry manure and vermicompost) along with chemical fertilizers exhibited remarkable positive effect on head height of cabbage. The highest head height $(14.2 \mathrm{~cm})$ was observed from $\mathrm{T}_{4}$. The lowest head height (8.1 $\mathrm{cm}$ ) was recorded from $T_{5}$. But use of only inorganic fertilizers is harmful for soil health. So, we should try to supplement a part of chemical fertilizer by organic fertilizers and application of vermicompost and other organic fertilizers gave better performance for increased head height of cabbage. Organic fertilizers can serve as alternative practice to mineral fertilizers for improving soil structure and microbial biomass (Dauda et al., 2008).

\section{Total weight of cabbage plant ${ }^{-1}$}

Effects of different levels of organic fertilizers (cowdung, poultry manure and vermicompost) on weight of cabbage were found significant $(\mathrm{P} \leq 0.05)$ (Table 04). The maximum total weight $(2.4 \mathrm{~kg} / \mathrm{plant})$ was recorded in $\mathrm{T}_{4}$ treatment. The lowest weight $(1.1 \mathrm{~kg} / \mathrm{plant})$ was obtained in $\mathrm{T}_{5}$. Our results are in harmony with the findings of Noor et al. (2005). Application of organic manures improve the soil environmental and increase the microbial activity might increase the nutrient availability for cabbage production and thus increase the total weight of cabbage as compared to the sole application of chemical fertilizers.

\section{Marketable weight of cabbage plant ${ }^{-1}$}

Use of different level of organic fertilizers along with inorganic fertilizers increased the marketable weight of cabbage significantly (Table 04 ) at the $5 \%$ level. Among different types of organic fertilizers (vermicompost, cowdung and poultry manure) in combination with inorganic fertilizers, the highest marketable weight $(2.3 \mathrm{~kg} /$ plant $)$ was recorded from $\mathrm{T}_{4}$ treatment which was statistically significant from $\mathrm{T}_{1}(1.9 \mathrm{~kg} / \mathrm{plant}), \mathrm{T}_{2}(2.1 \mathrm{~kg} / \mathrm{plant})$ and $\mathrm{T}_{5}(1.0 \mathrm{~kg} / \mathrm{plant})$ except $\mathrm{T}_{3}(2.2 \mathrm{~kg} / \mathrm{plant})$, respectively. The lowest marketable weight was observed from $\mathrm{T}_{5}(1.0 \mathrm{~kg} / \mathrm{plant})$ treatment. These results are in agreement with those of (Das et al., 2002).

\section{Total yield of cabbage ( $t / h a)$}

Application of different doses of organic fertilizers exhibited significant $(\mathrm{P} \leq 0.05)$ influence on the total yield of cabbage (Figure 01). Total yield means yield of head along with unfolded leaves of cabbage. Among the different treatments the highest total yield (101.4 t/ha) was observed in $\mathrm{T}_{4}$ treatment which was significantly different from $\mathrm{T}_{1}(86.1 \mathrm{t} / \mathrm{ha}), \mathrm{T}_{2}(93.1 \mathrm{t} / \mathrm{ha})$ and $\mathrm{T}_{5}(47.2 \mathrm{t} / \mathrm{ha})$ except $\mathrm{T}_{3}(97.2 \mathrm{t} / \mathrm{ha})$, respectively. The lowest cabbage yield ( $47.2 \mathrm{t} / \mathrm{ha}$ ) was recorded in $\mathrm{T}_{5}$ treatment where no fertilizer was applied. Treatments having vermicompost along with IPNS based CF showed better yield than other 
organic fertilizers in increasing the yield of cabbage. But it was notable that, without chemical fertilizers vermicompost or other organic fertilizers could not give better yield.

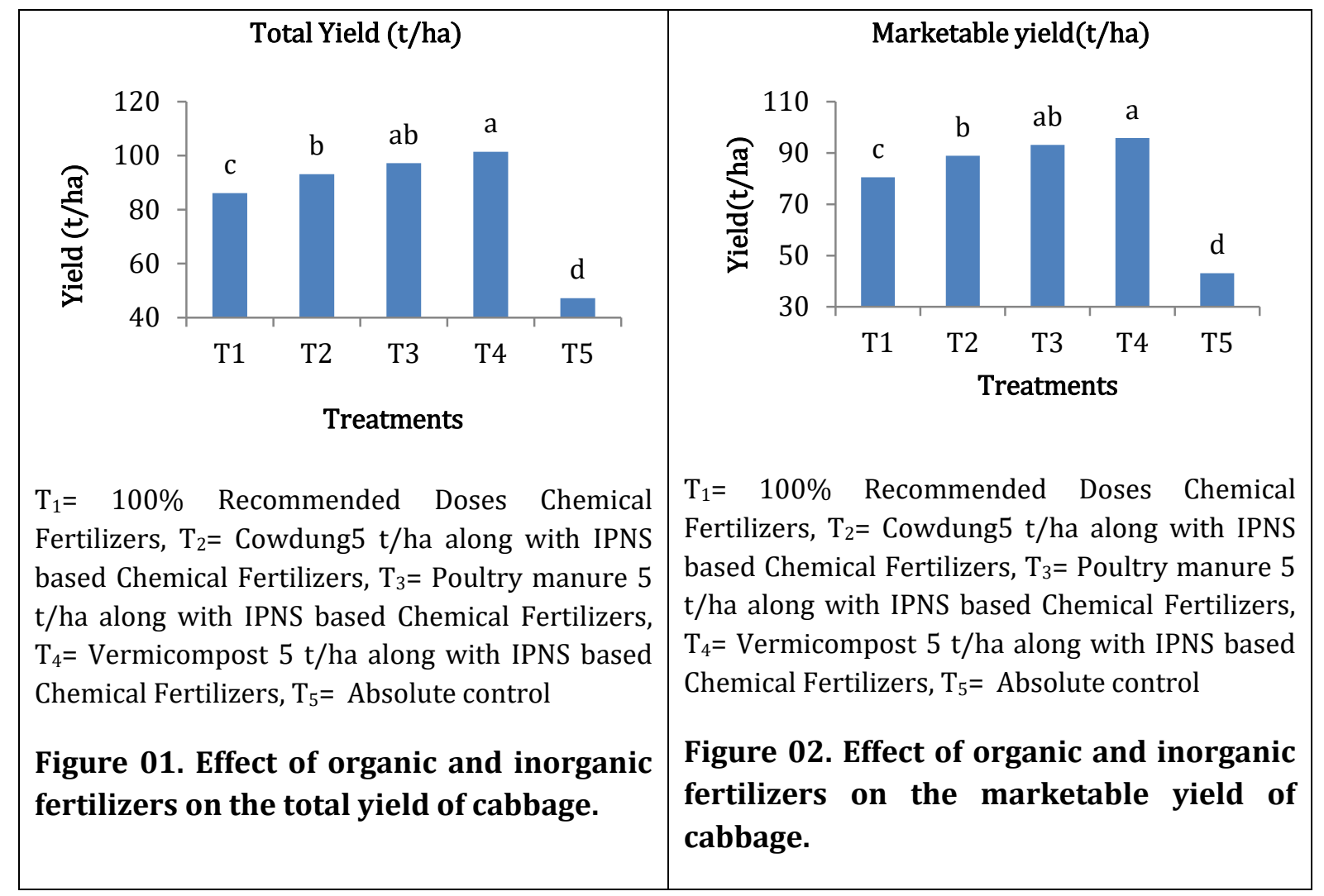

\section{Marketable yield of cabbage ( $t / h a)$}

Significant $(\mathrm{P} \leq 0.05)$ variation of marketable yield was observed among the treatments (Figure 02). Marketable yield means just edible head yield of cabbage without unfolded leaves. The highest marketable yield (95.8 t/ha) was obtained in $\mathrm{T}_{4}$ treatment which was statistically significant with all other treatments except $T_{3}$ treatment. The lowest marketable yield was observed in $T_{5}(43.1 \mathrm{t} / \mathrm{ha})$ treatment. These findings are in agreement with those of Liu and Li (2003).

\section{Effect of organic fertilizers and inorganic fertilizers on the nutrient content and uptake by cabbage}

\section{Nitrogen content in cabbage}

The highest nitrogen content in cabbage (1.90\%) was recorded from $\mathrm{T}_{4}$ treatment (Figure 03). This result was statistically $(\mathrm{P} \leq 0.05)$ superior to all other treatments except $\mathrm{T}_{3}$ treatment. The lowest value was found in $\mathrm{T}_{5}(0.96 \%)$ where no organic and inorganic fertilizers were applied. Earthworm casts typically have higher amount of total and available nitrogen, organic matter, total and exchangeable calcium, magnesium, potassium and available phosphorous compared to surface soils (Lavelle and Martin, 1992). Apart from providing the more available nutrient to plants, plant growth regulators belonging to the auxin, gibberellin and cytokinin groups present in the earthworm worked materials, are produced by wide range of soil microorganisms, many of which live in the casts (Tomati et al., 1983).

Earthworm casts had higher numbers of cellulolytic aerobes and hemi cellulolytic, amylolytic, nitrifying and denitrifying bacteria than the soil in which they lived (Elliott et al., 1990). Lee (1992) reported that microorganisms in the worm casts may fix atmospheric $\mathrm{N}$ in quantities that are significant for the earthworm metabolism and as a source of nitrogen for plant growth. 


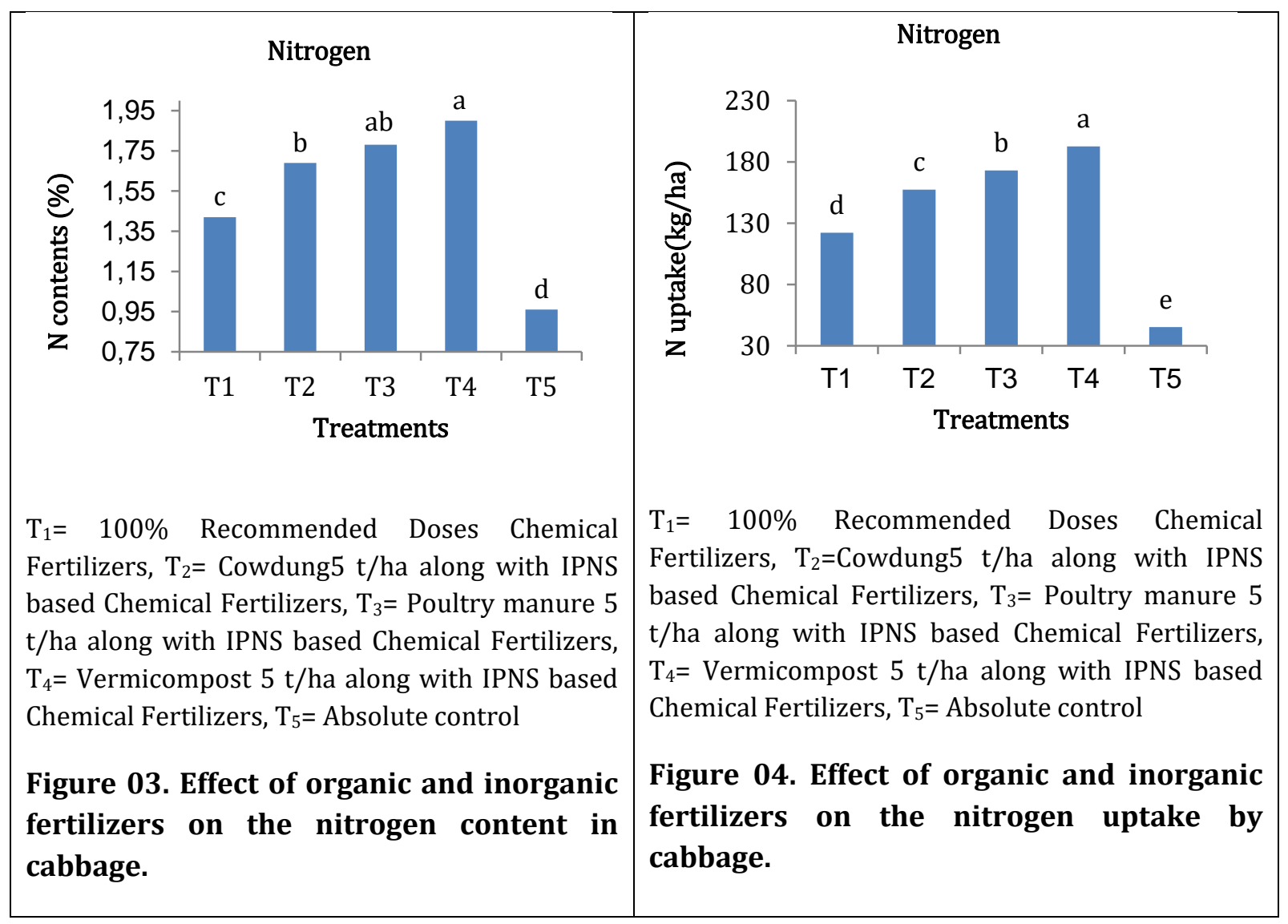

\section{Nitrogen uptake by cabbage}

A statistically significant $(\mathrm{P} \leq 0.05)$ variation was observed in nitrogen uptake by cabbage at harvest for different treatments (Figure 04). The highest nitrogen uptake $\left(192.7 \mathrm{~kg} / \mathrm{ha}\right.$ ) was recorded in $\mathrm{T}_{4}$ treatment which was statistically significant from $\mathrm{T}_{1}, \mathrm{~T}_{2}$ and $\mathrm{T}_{3}$ treatments and the given results were $(122.2 \mathrm{~kg} / \mathrm{ha}),(157.3 \mathrm{~kg} / \mathrm{ha})$ and $(173.0 \mathrm{~kg} / \mathrm{ha})$ and the lowest nitrogen uptake $(45.3 \mathrm{~kg} / \mathrm{ha})$ was recorded in $\mathrm{T}_{5}$ treatment. Jat and Ahlawat (2004) reported that application of vermicompost to chickpea improved nitrogen and phosphorous uptake by the cropping system.Vermicompost is a potential source of readily available nutrients, growth enhancing substance and a number of beneficial microorganisms like $\mathrm{N}$ fixing, P solubilizing and cellulose decomposing organisms (Vimala et al., 2006).

\section{Phosphorous content in cabbage}

Organic fertilizers significantly increased the phosphorus content in cabbage as compared to the inorganic fertilizer treated plots. Effect of organic fertilizers along with chemical fertilizers on phosphorous in cabbage was also found significant (Figure 05). Highest content of phosphorous in cabbage was found $(0.34 \%)$ in $\mathrm{T}_{4}$ treatment which was statistically superior to all other treatments. The lowest phosphorous content $(0.14 \%)$ was found from $\mathrm{T}_{5}$ treatment. The results indicated that the application of organic fertilizers increased efficiency of chemical fertilizer and phosphorous uptake in cabbage. (Dixit and Gupta, 2000).

\section{Phosphorous uptake by cabbage}

Significant $(\mathrm{P} \leq 0.05)$ variation was recorded in phosphorous uptake by cabbage when organic fertilizers with chemical fertilizers were applied (Figure 06). Considering the effect of different types of fertilizers, the highest phosphorous uptake $(34.5 \mathrm{~kg} / \mathrm{ha})$ was recorded in $\mathrm{T}_{4}$ treatment which was statistically significant from other treatments and the lowest phosphorous uptake $(6.6 \mathrm{~kg} / \mathrm{ha})$ was recorded in $\mathrm{T}_{5}$ treatments. These results were in agreement with those of (Manivannam et al., 2009). 


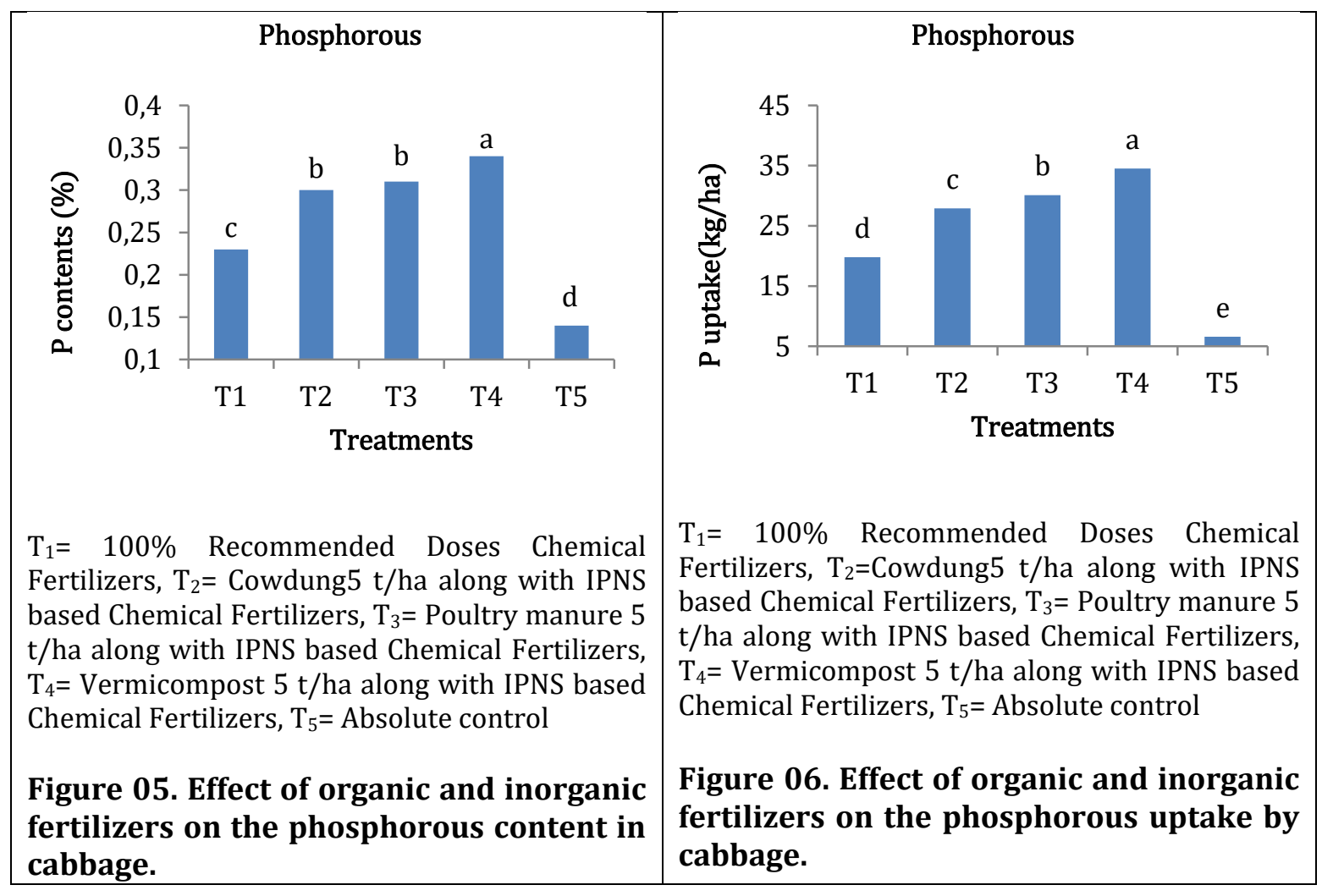

\section{Potassium content in cabbage}

Maximum potassium content in cabbage $(1.4 \%)$ was recorded in $\mathrm{T}_{4}$ treatment which was statistically significant $(\mathrm{P} \leq 0.05)$ over all other treatments (Figure 07$)$. The lowest potassium $(0.90 \%)$ was obtained from $\mathrm{T}_{5}$ treatments. Similar result was stated by (Klara, 1998).

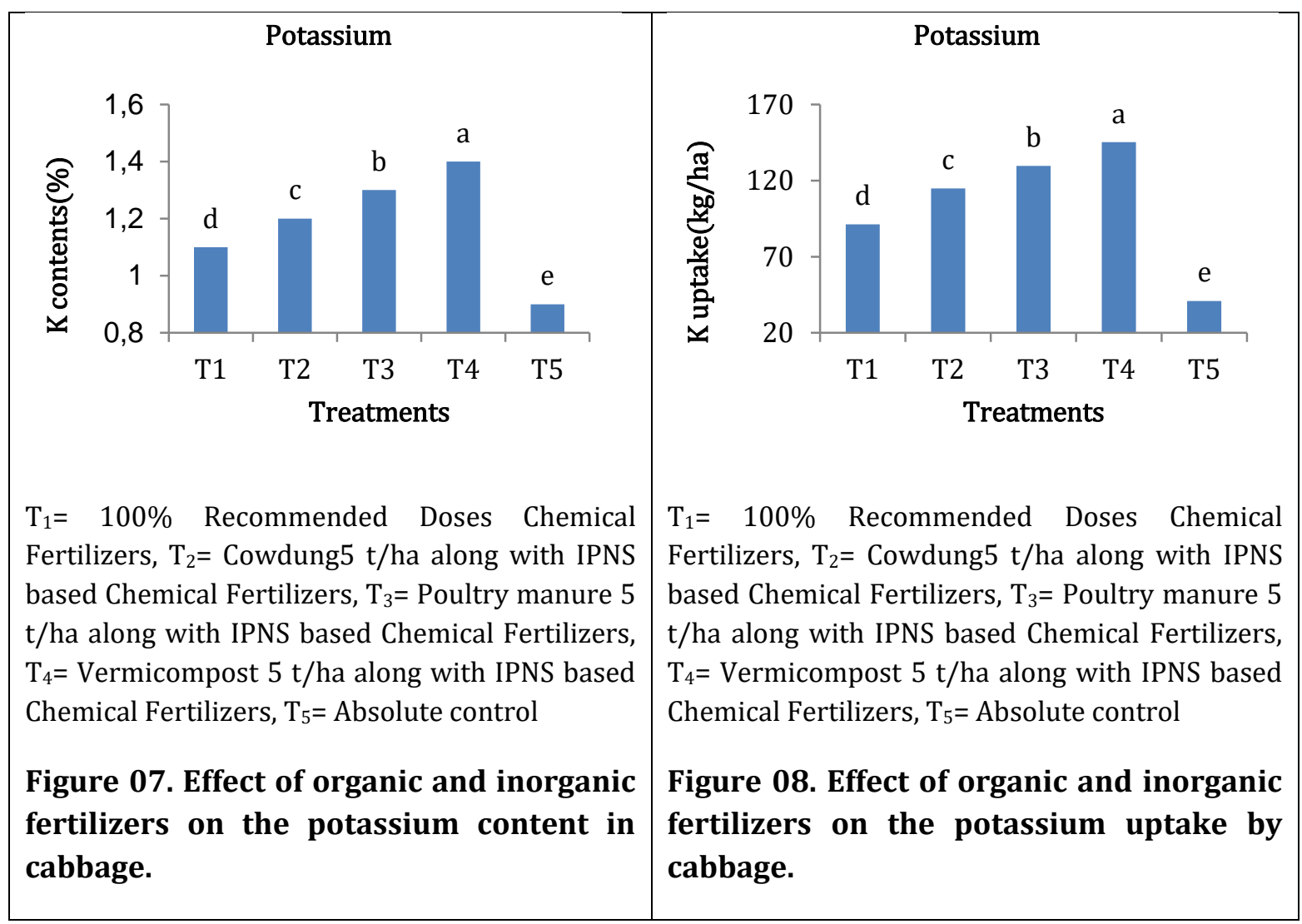




\section{Potassium uptake by cabbage}

Different treatments showed a significant $(\mathrm{P} \leq 0.05)$ variation in the potassium uptake by cabbage (Figure 08). The highest potassium uptake $(145.2 \mathrm{~kg} / \mathrm{ha})$ was recorded in $\mathrm{T}_{4}$ treatment which was statistically significant with other treatments. The lowest potassium uptake $(40.90 \mathrm{~kg} / \mathrm{ha})$ was recorded in $\mathrm{T}_{5}$. Application of chemical fertilizers with different types of organic fertilizers showed significant variation in respect of potassium uptake by cabbage. Bongkyoon (2004) reported that the effect of vermicompost (EVC) application were favorable than the effect of the application of a chemical fertilizers in case of both yields and content and uptake of nutrients of crops.

\section{Sulfur content in cabbage}

The maximum sulfur content in cabbage $(0.17 \%)$ was found in $\mathrm{T}_{4}$ treatment. The result was statistically significant $(\mathrm{P} \leq 0.05)$ with the other treatments and statistically superior over all other treatments. The lowest sulfur $(0.05 \%)$ was found in $\mathrm{T}_{5}$ treatment (Table 05). Similar result was stated by (Klara, 1998).

Table 05. Effect of organic and inorganic fertilizers on the sulfur and zinc content in cabbage and uptake by cabbage

\begin{tabular}{|c|c|c|c|c|c|c|c|c|c|c|}
\hline & $S$ & $S$ & $\mathrm{Zn}$ & $\mathrm{Zn}$ & B & B & $\mathrm{Ca}$ & $\mathrm{Ca}$ & $\mathrm{Mg}$ & $\mathrm{Mg}$ \\
\hline Tre & $\begin{array}{c}\text { contents } \\
(\%)\end{array}$ & $\begin{array}{l}\text { uptake } \\
\text { (kg/ha) }\end{array}$ & $\begin{array}{c}\text { contents } \\
(\%)\end{array}$ & $\begin{array}{l}\text { uptake } \\
\text { (kg/ha) }\end{array}$ & $\begin{array}{c}\text { contents } \\
(\%)\end{array}$ & $\begin{array}{l}\text { uptake } \\
\text { (kg/ha) }\end{array}$ & $\begin{array}{c}\text { contents } \\
(\%)\end{array}$ & $\begin{array}{l}\text { uptake } \\
(\mathrm{kg} / \mathrm{ha})\end{array}$ & $\begin{array}{c}\text { contents } \\
(\%)\end{array}$ & $\begin{array}{l}\text { uptake } \\
\text { (kg/ha) }\end{array}$ \\
\hline T1 & $0.12 \mathrm{c}$ & $10.3 \mathrm{~d}$ & $0.024 \mathrm{~d}$ & $2.1 \mathrm{~d}$ & $0.017 \mathrm{c}$ & $1.5 \mathrm{c}$ & $0.53 \mathrm{~d}$ & $45.6 \mathrm{~d}$ & $0.27 \mathrm{~b}$ & $23.2 \mathrm{~d}$ \\
\hline $\mathrm{T} 2$ & $0.13 \mathrm{c}$ & $12.1 \mathrm{c}$ & $0.028 \mathrm{c}$ & $2.6 \mathrm{c}$ & $0.019 \mathrm{~b}$ & $1.8 \mathrm{~b}$ & $0.58 \mathrm{c}$ & $54.0 \mathrm{c}$ & $0.29 \mathrm{~b}$ & $27.0 \mathrm{c}$ \\
\hline T3 & $0.15 \mathrm{~b}$ & $14.6 \mathrm{~b}$ & $0.031 \mathrm{~b}$ & $3.0 \mathrm{~b}$ & $0.019 \mathrm{~b}$ & $1.8 \mathrm{~b}$ & $0.62 \mathrm{~b}$ & $60.3 \mathrm{~b}$ & $0.31 \mathrm{~b}$ & $30.1 \mathrm{~b}$ \\
\hline $\mathrm{T} 4$ & $0.17 \mathrm{a}$ & $17.2 \mathrm{a}$ & $0.035 \mathrm{a}$ & $3.5 \mathrm{a}$ & $0.020 \mathrm{a}$ & $2.0 \mathrm{a}$ & $0.67 \mathrm{a}$ & $67.9 \mathrm{a}$ & $0.34 \mathrm{a}$ & $34.5 \mathrm{a}$ \\
\hline T5 & $0.05 \mathrm{~d}$ & $2.4 \mathrm{e}$ & $0.020 \mathrm{e}$ & $0.9 \mathrm{e}$ & $0.013 \mathrm{~d}$ & $0.6 \mathrm{~d}$ & $0.40 \mathrm{e}$ & $18.9 \mathrm{e}$ & $0.17 \mathrm{e}$ & $8.0 \mathrm{e}$ \\
\hline LSD 0.05 & 0.0133 & 0.8375 & 0.0185 & 0.1140 & 0.0012 & 0.0688 & 0.0199 & 0.8375 & 0.0206 & 0.8371 \\
\hline CV (\%) & 5.73 & 3.93 & 3.54 & 2.50 & 2.96 & 2.36 & 1.88 & 0.90 & 2.23 & 1.81 \\
\hline
\end{tabular}

\section{Sulfur uptake by cabbage}

Statistically significant $(P \leq 0.05)$ variation was recorded in sulfur uptake by cabbage when different types of organic along with inorganic fertilizers were applied (Table 05). However, the highest sulfur uptake $\left(17.2 \mathrm{~kg} / \mathrm{ha}\right.$ ) was recorded in $\mathrm{T}_{4}$ which was significantly different from $\mathrm{T}_{1}, \mathrm{~T}_{2}, \mathrm{~T}_{3}$ and the results were found (10.3 kg/ha), (12.1 kg/ha) and (14.6 kg/ha), respectively. The lowest sulfur uptake $(2.4$ $\mathrm{kg} / \mathrm{ha}$ ) was recorded from $\mathrm{T}_{5}$ treatment.

\section{Zn content in cabbage}

The maximum zinc content in cabbage $(0.035 \%)$ was obtained from $\mathrm{T}_{4}$ treatment which was statistically significant $(\mathrm{P} \leq 0.05)$ to all other treatments. The lowest zinc $(0.020 \%)$ was recorded from $\mathrm{T}_{5}$ (Table 05$)$. Similar result was referred by (Klara, 1998).

\section{Zn uptake by cabbage}

Application of different sources of organic and inorganic fertilizers showed a significant $(\mathrm{P} \leq 0.05)$ variation in the zinc uptake by cabbage (Table 05). The highest zinc uptake ( $3.5 \mathrm{~kg} / \mathrm{ha}$ ) was recorded in $\mathrm{T}_{4}$ which was statistically significant from all other treatments. The lowest zinc uptake $(0.9 \mathrm{~kg} / \mathrm{ha})$ was recorded in $\mathrm{T}_{5}$ treatment where no chemical or organic fertilizers were applied.

\section{Boron content in cabbage}

After harvest maximum boron contents in cabbage $(0.020 \%)$ was obtained fromvermicompost treated plots ( $\mathrm{T}_{4}$ treatments) which was statistically significant $(\mathrm{P} \leq 0.05)$ from others treatments (Table 05 ) except $\mathrm{T}_{3}$. The lowest boron $(0.013 \%)$ was recorded in $\mathrm{T}_{5}$. The results of our study were well supported by (Klara, 1998). 


\section{Boron uptake by cabbage}

Statistically significant $(\mathrm{P} \leq 0.05)$ variation was recorded in boron uptake by cabbage when different types of organic along with inorganic fertilizers were applied (Table 05). However, the highest boron uptake $(2.0 \mathrm{~kg} / \mathrm{ha})$ was recorded in $\mathrm{T}_{4}$ treatments which is statistically significant from all other treatments. The lowest boron uptake $(0.6 \mathrm{~kg} / \mathrm{ha})$ was recorded from $\mathrm{T}_{5}$.

\section{Calcium content in cabbage}

As for calcium content in cabbage after harvest in $\mathrm{T}_{4}$ treatment showed the highest calcium content $(0.67 \%)$ which was statistically different $(\mathrm{P} \leq 0.05)$ from all other treatments. The lowest value was found $(0.40 \%)$ in $\mathrm{T}_{5}$ treatment (Table 05$)$.

\section{Calcium uptake by cabbage}

Statistically significant $(\mathrm{P} \leq 0.05)$ variation was observed among the treatments where $\mathrm{T}_{4}$ treatment showed the $(67.9 \mathrm{~kg} / \mathrm{ha})$ highest calcium uptake by cabbage which was superior to all other treatments (Table 05). Second highest calcium $(60.3 \mathrm{~kg} / \mathrm{ha})$ was recorded from $\mathrm{T}_{3}$ treatment which was also significant from other treatments. The lowest calcium uptake was obtained in $\mathrm{T}_{5}(18.9 \mathrm{~kg} / \mathrm{ha})$ treatment.

\section{Magnesium content in cabbage}

$\mathrm{T}_{4}$ Treatment showed the highest magnesium content $(0.34 \%)$ which was statistically $(\mathrm{P} \leq 0.05)$ significant from $\mathrm{T}_{1}, \mathrm{~T}_{2}$ and $\mathrm{T}_{5}$ except $\mathrm{T}_{3}$ treatment (Table 05 ). The lowest value was obtained from $\mathrm{T}_{5}$ $(0.17 \%)$ treatment. Similar result was referred by (Klara, 1998).

\section{Magnesium uptake by cabbage}

Statistically significant $(\mathrm{P} \leq 0.05)$ variation was recorded in $\mathrm{T}_{4}$ treatments which was superior from all other treatments. The highest magnesium uptake $\left(34.5 \mathrm{~kg} / \mathrm{ha}\right.$ ) was recorded from $\mathrm{T}_{4}$ treatment (Table 05). The lowest ( $8.0 \mathrm{~kg} / \mathrm{ha})$ was obtained in $\mathrm{T}_{5}$ treatment.

\section{Effect of organic and inorganic fertilizers on the nutrients status of soil after harvest $\mathrm{pH}$ in soil}

After harvest, significant $(\mathrm{P} \leq 0.05)$ variation of $\mathrm{pH}$ was found in $\mathrm{T}_{4}(\mathrm{pH}=6.53)$ treatment (Table 06) which was significantly different from others treatments. The lowest $\mathrm{pH}$ value was found in $\mathrm{T}_{1}$ $(\mathrm{pH}=6.06)$ treatment which was statistically similar with $\mathrm{T}_{2}, \mathrm{~T}_{5}$ treatments. It is noted that initial soil $\mathrm{pH}$ was 6.2 .

\section{Organic carbon in soil}

A significant variation $(\mathrm{P} \leq 0.05)$ was recorded in the organic carbon content of post harvest soil samples as influenced by the application of different organic along with inorganic fertilizers (Table 06). Among the treatments, $\mathrm{T}_{4}$ treatment showed the highest organic carbon content $(1.11 \%)$. On the other hand lowest organic carboncontent $(0.51 \%)$ was observed in $\mathrm{T}_{5}$ treatment. Similar results were reported by (kamal et al., 2002) who explained that soil organic carbon increased when organic fertilizers were supplied instead of NPK fertilizers. It is noteworthy that organic carbon content of the initial soil sample was $0.8 \%$.

\section{Total nitrogen content in soil}

Significant $(\mathrm{P} \leq 0.05)$ variation was recorded on the nitrogen content of cabbage field after harvest of the crop when field was treated with different doses of organic and inorganic fertilizers (Table 06). The highest total nitrogen $(0.11 \%)$ was found in $_{4}$. The lowest $(0.06 \%)$ was found in $\mathrm{T}_{5}$ treatment. Bangar et al. (1990) found that organic fertilizers enriched the nitrogen content in soil. This might have happened due to the nitrogen accumulation in soil by the mineralization of organic nitrogen. The initial soil $\mathrm{N}$ was (0.058). 
J. Sci. Technol. Environ. Inform. 03(02): 231-244 | Reza et al. (2016)

EISSN: 2409-7632, www.journalbinet.com

DOI: $10.18801 /$ jstei.030216.26

Table 06. Effect of organic and inorganic fertilizers on the $\mathrm{pH}, \% \mathrm{OC}$, exchangeable $\mathrm{K}, \mathrm{Ca}, \mathrm{Mg}$, total $\mathrm{N}$, available $\mathrm{P}, \mathrm{S}, \mathrm{Zn}$ and $\mathrm{B}$ in soil after harvest

\begin{tabular}{|c|c|c|c|c|c|c|c|c|c|c|}
\hline \multirow{2}{*}{ Treatments } & \multirow{2}{*}{$\mathrm{H}$} & \multirow{2}{*}{ OC $(\%)$} & $\mathrm{K}$ & $\mathrm{Ca}$ & $\mathrm{Mg}$ & \multirow{2}{*}{$\begin{array}{c}\text { Total N } \\
(\%)\end{array}$} & \multirow{2}{*}{\multicolumn{4}{|c|}{$\frac{\mathrm{S}}{\mathrm{ppm}}$}} \\
\hline & & & \multicolumn{3}{|c|}{ Meq/100 g soil } & & & & & \\
\hline T1 & 6 & 0 & 0 & c & $\mathrm{d}$ & $d$ & $d$ & $\begin{array}{c}13.33 \\
d\end{array}$ & $\mathrm{~b}$ & $18 \mathrm{~d}$ \\
\hline $\mathrm{T} 2$ & c & 1.0 & bc & $9.25 \mathrm{~b}$ & $3.52 \mathrm{c}$ & & $7 \mathrm{c}$ & $\begin{array}{c}15.33 \\
c\end{array}$ & $\begin{array}{c}1.91 \\
\mathrm{ab}\end{array}$ & $0.22 \mathrm{c}$ \\
\hline T3 & $6.3 \mathrm{~b}$ & $1.06 \mathrm{~b}$ & $0.29 \mathrm{~b}$ & $9.54 \mathrm{a}$ & $3.63 \mathrm{~b}$ & $0.09 \mathrm{~b}$ & $18.10 \mathrm{~b}$ & $\begin{array}{c}16.68 \\
b\end{array}$ & $\begin{array}{c}1.92 \\
\mathrm{ab}\end{array}$ & $0.24 \mathrm{~b}$ \\
\hline $\mathrm{T} 4$ & & & $0.32 \mathrm{a}$ & $9.75 \mathrm{a}$ & $3.73 \mathrm{a}$ & $0.11 \mathrm{a}$ & $21.63 \mathrm{a}$ & $\begin{array}{c}17.93 \\
a\end{array}$ & $1.94 \mathrm{a}$ & $0.26 \mathrm{a}$ \\
\hline $\mathrm{T} 5$ & $6.2 \mathrm{c}$ & & $0.20 \mathrm{~d}$ & $5.25 \mathrm{~d}$ & $2.01 \mathrm{e}$ & $0.06 \mathrm{~d}$ & $10.19 \mathrm{e}$ & $9.33 \mathrm{e}$ & $1.17 \mathrm{c}$ & $0.09 \mathrm{e}$ \\
\hline (D/ & 0.2275 & 0.0 & 0.0286 & 0.3516 & 0.0450 & 0.0135 & 0.6798 & 0.4861 & 0.0375 & $\begin{array}{c}0.119 \\
301\end{array}$ \\
\hline . & & & 5.59 & 2.23 & 5 & & 2.24 & 1.59 & 1.1 & 1 \\
\hline
\end{tabular}

Available phosphorous in soil

Phosphorous content of postharvest soil showed significant $(\mathrm{P} \leq 0.05)$ variation for different treatments (Table 06). Combined effect of different types of organic and inorganic fertilizers recorded significant variation of available phosphorous content in postharvest soil. Among the different treatments, the highest available phosphorous (21.63 ppm) was found in $\mathrm{T}_{4}$ which was statistically superior to all other treatments. The lowest (10.19 ppm) was found in $\mathrm{T}_{5}$. Guan (1989) reported that the application of organic fertilizers increased the availability of phosphorous in soil. The initial soil available p was (10ppm).

\section{Exchangeable Potassium, Calcium and Magnesium content in soil}

Significant $(\mathrm{P} \leq 0.05)$ variation was recorded in exchangeable $\mathrm{K}, \mathrm{Ca}$ and $\mathrm{Mg}$ content in soil after harvest of the cabbage which is shown in Table 06. The highest $\mathrm{K}, \mathrm{Ca}$ and $\mathrm{Mg}$ were $(0.32 \mathrm{meq} / 100 \mathrm{~g}$ soil, $9.75 \mathrm{meq} / 100 \mathrm{~g}$ soil and $3.73 \mathrm{meq} / 100 \mathrm{~g}$ soil, respectively) found in $\mathrm{T}_{4}$ treatment. On the other hand the lowest $\mathrm{K}, \mathrm{Ca}$ and $\mathrm{Mg}$ were $(0.20 \mathrm{meq} / 100 \mathrm{~g}$ soil, $5.25 \mathrm{meq} / 100 \mathrm{~g}$ soil and $2.01 \mathrm{meq} / 100 \mathrm{~g}$ soil, respectively) were obtained from $\mathrm{T}_{5}$ treatment. Ramalingam (1999) reported that vermicompost increased significantly potassium by $40 \%$ over the control. It is noteworthy that the initial soil $\mathrm{K}$, Ca and Mg were $0.12 \mathrm{meq} / 100 \mathrm{~g}$ soils, $8.75 \mathrm{meq} / 100 \mathrm{~g}$ soil sand $2.46 \mathrm{meq} / 100 \mathrm{~g}$ soil, respectively.

\section{Available sulfur, Zinc and Boron in soil}

Significant $(\mathrm{P} \leq 0.05)$ variation was recorded in sulfur, zinc and boron content in soil after cabbage harvest where the plots were incorporated with different doses of organic and inorganic fertilizers in the (Table 06). The highest sulfur $(17.93 \mathrm{ppm})$, zinc $(1.94 \mathrm{ppm})$ and boron $(0.26 \mathrm{ppm})$ were found in $\mathrm{T}_{4}$ treatment. The lowest sulfur $(9.33 \mathrm{ppm})$, zinc $(1.17 \mathrm{ppm})$ and boron $(0.09 \mathrm{ppm})$ were found in $\mathrm{T}_{5}$ treatment.The initial soil S, B and $\mathrm{Zn}$ were $15 \mathrm{ppm}, 0.20 \mathrm{ppm}$ and $1.1 \mathrm{ppm}$, respectively. Vasanthi and Kumaraswamy (1999) showed from an experiment with vermicompost and NPK fertilizers that organic carbon content and fertility status as reflected by the available status of micronutrients such as zinc were higher and bulk density were lower in the treatments that received vermicompost plus $\mathrm{N}, \mathrm{P}$ and $\mathrm{K}$ than in the treatments with $\mathrm{N}, \mathrm{P}$ and $\mathrm{K}$ alone.

\section{Conclusion}

The result revealed that when vermicompost was applied in combination with integrated plant nutrient system along with recommended doses chemical fertilizers, the effect showed better performance on yield rather than applying chemical fertilizers alone. Thus we conclude that vermicompost can be used either in combination with fertilizers or alone for satisfactory yield of cabbage. 


\section{Acknowledgement}

The experiment was conducted as thesis work for the partial fulfillment of master degree by the first author Md. Selim Reza. Authors are highly grateful to department of Soil Science, Bangabandhu Sheikh Mujibur Rahman Agricultural University, Gazipur, Bangladesh. This experiment was supported and funded by supervisors of the work.

\section{References}

1. Ali, M. M., Shaheed, S. M. \& Kubota, D. (1997). Soil degradation during the period 1967-1995 in Bangladesh. II Selected chemical characters. Soil Sci. and Plant Nutr. 43(4), 879-890. http://dx.doi.org/10.1080/00380768.1997.10414654

2. Bangar, K. C., Shanker, S., Kapoor, K. K., Kukreja, K. \& Mishra, M. M. (1990). Preparation of nitrogen and phosphorous enriched paddy straw carry out and its effect on yield and nutrients uptake by wheat. Biol. Fert. Soils. 8 (4), 339-342.

3. Bangladesh Agricultural Research Council (BARC) (2005). Fertilizer Recommendation Guide2005, BARC, Soils Pub., No. 45, Bangladesh Agri. Res. Council, Farm gate, Dhaka.

4. Bangladesh Agricultural Research Council (BARC) (2012). Fertilizer Recommendation Guide2012, BARC, Soils Pub., No. 45, Bangladesh Agri. Res. Council, Farm gate, Dhaka.

5. Bangladesh Agricultural Research Institute (BARI) (2009). Effect of vermicompost and compost on the yield and yield components of cauliflower. Annual research report (2008-2009). pp. 127133.

6. Batsai, S. T., Polyakev, A. A. \& Nedbal, R. F. (1997). Effects of organic and mineral fertilizers on the yield and quality of irrigated late white cabbage in the steppe region of the Crimea. Hort. Abst. 49 (11), 730.

7. Black, G. R. (1965). Bulk density. In: Black, C. A. (ed.). Methods of Soil analysis, Part 1. American Society of Agronomy, Monograph Series no. 9, 374-390.

http://dx.doi.org/10.2134/agronmonogr9.1.c30

8. Blatt, C. R. (1991). Comparison of several organic amendments with a chemical fertilizer for vegetable production. Sci. Hort. 47, 177-191. http://dx.doi.org/10.1016/0304-4238(91)90001-F

9. Bongkyoon, K. (2004). Effect of vermicompost on growth of fall- cropping potato in volcanic ash soil. Korean J. Crop. Sci. 49(4), 305-308.

10. Das, P.K., Jen, M. K. \& Sahoo, K. C. (2002). Effect of integrated application of vermicompost and chemical fertilizer on growth and yield of paddy in red soil of South Easter Ghat Zone of Orissa. Envir.and Eco. 20(1), 13-15.

11. Dauda, S. N., Ajayi, F. A. \& Noor, E. (2008). Growth and yield of water melon (Citrullus lanatus) as affected by poultry manure application. J. Agric. Soc. Sci. 4, 121-4.

12. Dixit, K. G. \& Gupta, B. R. (2000). Effect of farmyard manure, chemical and bio-fertilizers on yield and quality of rice (Oryza sativa L.) and soil properties. J. of Ind. Soci. of Soil Sci. 48, 773-780.

13. Elliott, T. E., Cambardella, C. A. \& Barret, P. (1990). Methods for physical separation and characterization of soil organic matter fraction. Geoderma, 56, 449-457.

14. Gomez, K. A. \& Gomez, A. A. (1984). Statistically Procedures for Agricultural Research. $2^{\text {nd }}$ edition. An International Rice Research Institute Book. A wiley-Inter science Publication, New York, 28. pp. 442-443.

15. Guan, S. Y. (1989). Studies on the factors influencing soil enzyme activities: I. Effects of organic manures on soil enzyme activities and nitrogen and phosphorous transformations. Actapedologica-Sinice. 26 (I), 72-78.

16. Jackson, M. L. (1973). Soil chemical analysis. Advanced course. $2^{\text {nd }}$ ed. M. L. Jackson, Madison, WI.

17. Jat, R. S. \& Ahlawat, I. P. S. (2004). Direct and residual effect of vermicompost. Biofertilizers and Phosphorous on Soil Nutrient Dynamics and Productivity of Chickpea-fodder maize sequence. Indian J. Soil Sci. 12(2), 41-54.

18. Kale, R. D. \& Bano, K. (1986). Field trials with vermicompost (vee comp. E.83 UAS) an organic fertilizer. In: Dash, M. C., Senapati, B. K. \& Mishra, P.C. (Ed.). Proceeding National Seminar Org. 
Waste UtilizVermicom Part B: verms and vermicomposting. Five Star Printing Press. Burla, Orissa. Pp. 151-156.

19. Kamal, K., Paliyal, S. S. \& Nadal, T. R. (2002). Integrated nutrient management in cauliflower (Pusa Snow Ball K-1). CSKHPKV Regional Research Station, Dhaulakuan, Sirmour-173 001 (H. P.). India R. Crops. 3(3), 579-583.

20. Khan, M. S., Shil, N. C. \& Noor, S. (2008). Integrated nutrient management for sustainable yield of major vegetable crops in Bangladesh. Bangladesh J. Agric. Environ. 4, 81-94.

21. Klara, A. (1998). Essential nutrients in mature leaf tissues generalized as deficient, sufficient or excessive for various plant species. J. of the Envirn. And Nutri. Sci. 24(II), 25-27.

22. Krish, V. A., Peters, U., Mayne, S. T., Sabur, A. F., Chatterjee, N., Johnson, E. \& Hayers, R. B. (2007). Protective study of fruit and vegetables intake and risk of prostate cancer. J. of the Nation Can. Ins. 99 (15), 1200-1209. http://dx.doi.org/10.1093/jnci/djm065 PMid:17652276

23. Lavelle, P. \& Martin, A. (1992). Small scale and large scales effects of endogenic earthworms on soil organic matter dynamics in soils of the humid tropics. Soil Bio. and Bioche. 24, 1491-1498. http://dx.doi.org/10.1016/0038-0717(92)90138-N

24. Lee, K. E. (1992). Some trends and opportunities in earthworm research of Darwin's children. The future of our discipline. Soil Bio. Bioche. 24 (12), 1765-1771.

25. Liu, W. \& Li, S. (2003). Effects of organic nutrient solution on growth and quality of pak-choi under soilless culture. Acta Hort. 627, 139-144.

http://dx.doi.org/10.17660/ActaHortic.2003.627.17

26. Manivannam, S., Balamurugan, Parthasarathi, Gunasekharan, G. \& Ranganathan, R. (2009). Effects of vermicompost on soil fertility and crop productivity- beans (Phaseolus vulgaris). J. Environ. Biol. 30, 275-281.

27. Nelson, D. W. \& Sommers, L. E. (1982). Total carbon, organic carbon and organic matter. In: Page, A. L. (ed). Methods of soil analysis. Part 2, $2^{\text {nd }}$ ed. Agron. Monogr. 9, ASA and SSSA, Madison WI. pp. 539-580.

28. Noor, S., Farid, A. T. M., Shil, N. C. \& Sultan, S. (2005). Evaluation of some organic manure on the yield of cabbage under integrated nutrient management system. Bangladesh J. Agric. and Envir. $1(2), 53-59$.

29. Olsen, S. R. \& Sommers, L. E. (1982). Phosphorous. In: Page, A. L., Miller, R. H. \& Keeney, D. R. (eds.). Methods of soil analysis, part 2, Chemical and Microbiological properties, American Socie. of Agro. Inc. Madison, WI, USA, 403-430.

30. Payal, G., Asha, G. \& Santosh, S. (2006). Vermicompost of difference types of waste using Eiseniafoetida a comparative study. Biores. Tech. 97, 3, 391-395. http://dx.doi.org/10.1016/j.biortech.2005.03.009 PMid:16168639

31. Piper, C. S. (1966). Soil and plant analysis. Hans's publication, Bombay. P. 224.

32. Ramalingam, R. (1999). Vercomposting of crop residue sugarcane trash using an Indian egemic earthworm, Perionyxencavatus. Ind. J. Experi. Zoology, 4(2), 267-272.

33. Sunassee, S. (2001). Use of Litter for Vegetable Production. AMAS 2001. Food and Agricultural Research Council, Reduit, Mauritius. pp. 259-263.

34. Suthar, S. (2012). Impact of vermicompost and composted farmyard manure on growth and yield of garlic (Allium stivum L.) Field crop. Int. J. of Plant Prod. 3 (1), 27-38.

35. Thomas, G. W. (1982). Exchangeable cations. In: A.L. Page (ed.). Methods of soil analysis. Part 2: Chemical and microbiological properties (2nd ed.). American Society of Agronomy, Soil Science Society of America. 9. pp. 159-165.

36. Tindall, M. (2000). Mineral and organic fertilizing in cabbage. Residual effect for commercial cultivation on yield and quality performance with organic farming. Hort. Bras. 6, 15-20.

37. Tomati, U., Grappelli, A., Galli, E. \& Nizi, W. (1983). Fertilizer from vermiculture as an option from organic wastes recovery. Agroche. Acta, 27, 244-251.

38. Vasanthi, D. \& Kumaraswamy, K. (1999).Effect of vermicompost to improve soil fertility and rice yield. J. Ind. Soc. Soil Sci. 47 (2), 268-272. 
39. Vimala, P. M., Illias, K. \& Salbiah, H. (2006). Effect of rates of organic fertilizer on growth, yield and nutrient content of cabbage (Brassica oleracea var. captitata) growth under shelter. ActaHorticulturae, 710, 391-397. http://dx.doi.org/10.17660/ActaHortic.2006.710.47

40. Walker, D. J. \& Bernal, M. P. (2004). Plant mineral nutrition and growth in a saline Mediterranean soil amended with organic wastes. Commun. Soil Sci. Plant Anal. 35(17-18), 2495-2514. http://dx.doi.org/10.1081/LCSS-200030347

41. Zahid, H. M. (2001). Production of vermicompost and its use in Upland and Horticultural crops. Annual reports of Bangladesh Agricultural Research Council, Farmgate, Dhaka.

\section{How to cite this article?}

\section{APA (American Psychological Association)}

Reza, M. S., Islam, A. K. M. S., Rahman, M. A., Miah, M. Y., Akhter, S. \& Rahman, M. M. (2016). Impact of organic fertilizers on yield and nutrient uptake of cabbage (Brassica Oleracea var. capitata). Journal of Science, Technology and Environment Informatics, 03(02), 231-244.

\section{MLA (Modern Language Association)}

Reza, M. S., Islam, A. K. M. S., Rahman, M. A., Miah, M. Y., Akhter, S. \& Rahman, M. M. "Impact of organic fertilizers on yield and nutrient uptake of cabbage (Brassica Oleracea var. capitata)." Journal of Science, Technology and Environment Informatics, 03.02 (2016): 231-244.

\section{Chicago/Turabian}

Reza, M. S., Islam, A. K. M. S., Rahman, M. A., Miah, M. Y, Akhter, S. \& Rahman, M. M. "Impact of organic fertilizers on yield and nutrient uptake of cabbage (Brassica Oleracea var. capitata)." Journal of Science, Technology and Environment Informatics, 03, no. 02 (2016): 231-244.

\section{Submit article and publish with Journal BiNET.}

Key Features:

$\checkmark \quad$ Faster processing and review of article

$\checkmark \quad$ Quick review and editorial tasks

$\checkmark \quad$ International editorial and review board

$\checkmark \quad 21$ business day's rapid publication

$\checkmark \quad$ View and read articles powered by Scribd

$\checkmark$ Greater audience readership is ensured for all article

$\checkmark \quad$ Indexing and bibliographic integration of article

$\checkmark \quad$ Social sharing enabled article

Submit article (or email to submit@ journalbinet.com): http://www.journalbinet.com/article-submission-form.html 